\title{
CHAPTER 76
}

FIELD STUDY OF A TIDAL INIET, BIMINI, BAHAMAS ${ }^{\perp}$

W HARRISON, $R$ J BYRNE, J $D$ BOON, III, and $R$ W MONCURE

Division of Physical, Chemzcal, and Geologscal Oceanography Vırginza Instıtute of Marıne Science, Gloucester Point, Virginia 23062

\section{ABSTRACT}

The inlet bathymetry was mapped by standard photogrammetric technıques after photographing the bottom directly through the water column The channel bottom is bare beachrock or is floored with bloclastic sands and gravels $(S \mathrm{G}=284$ )

A nine-day time series of observations of current speed and direction, and water temperature and salinity was obtained at two depths at each of elght stations using tripod-mounted, telemetering sensor packages Twelve-to-18-minute pulsations in the flow were often observed Spectral analysis of near-surface current speeds shows significant peaks at 24 , $32,43,67$, and $123 \mathrm{hrs}$

Evolution of sand ripples and dunes was monctored over a 200-ft distance during one tidal cycle The pattern of growth illustrates the differences in bedform geometry which may be expected to influence friction coefficients Evidence is presented for a bottom jet that is induced by flow over the crests of sand waves

Tracer sand, sorted into two size groups and color-coded for identification, was released on a flood current sampling of color-coded tracer sand was conducted by divers using strips of grease-coated plastic tape Spatial distribution of tracers in relation to the bedforms, and the amportance to grain erosion of a natural mucold coating, are noted

\section{INTRODUCTION}

This study was designed to examine the hydrography and the flucdsediment interactions in an inlet floored with carbonate sand The approach adopted involved 1) describing the basic inlet geometry and the sem--permanent bedforms, 2) documenting the general flow field, 3) documenting the response of relatively small-scale bedforms to ebb and flood currents, and 4) conducting specıfic sand-tracer experiments

Morphologically speaknng, the inlet studied is a specialized tidal channel that connects waters of the Florlda Stralts with a shallow lagoon about elght square mlles in area (Fig I) The lagoon is not enclosed, but opens to the Great Bahama Bank across a broad area of flats

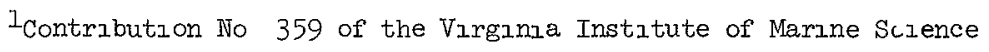




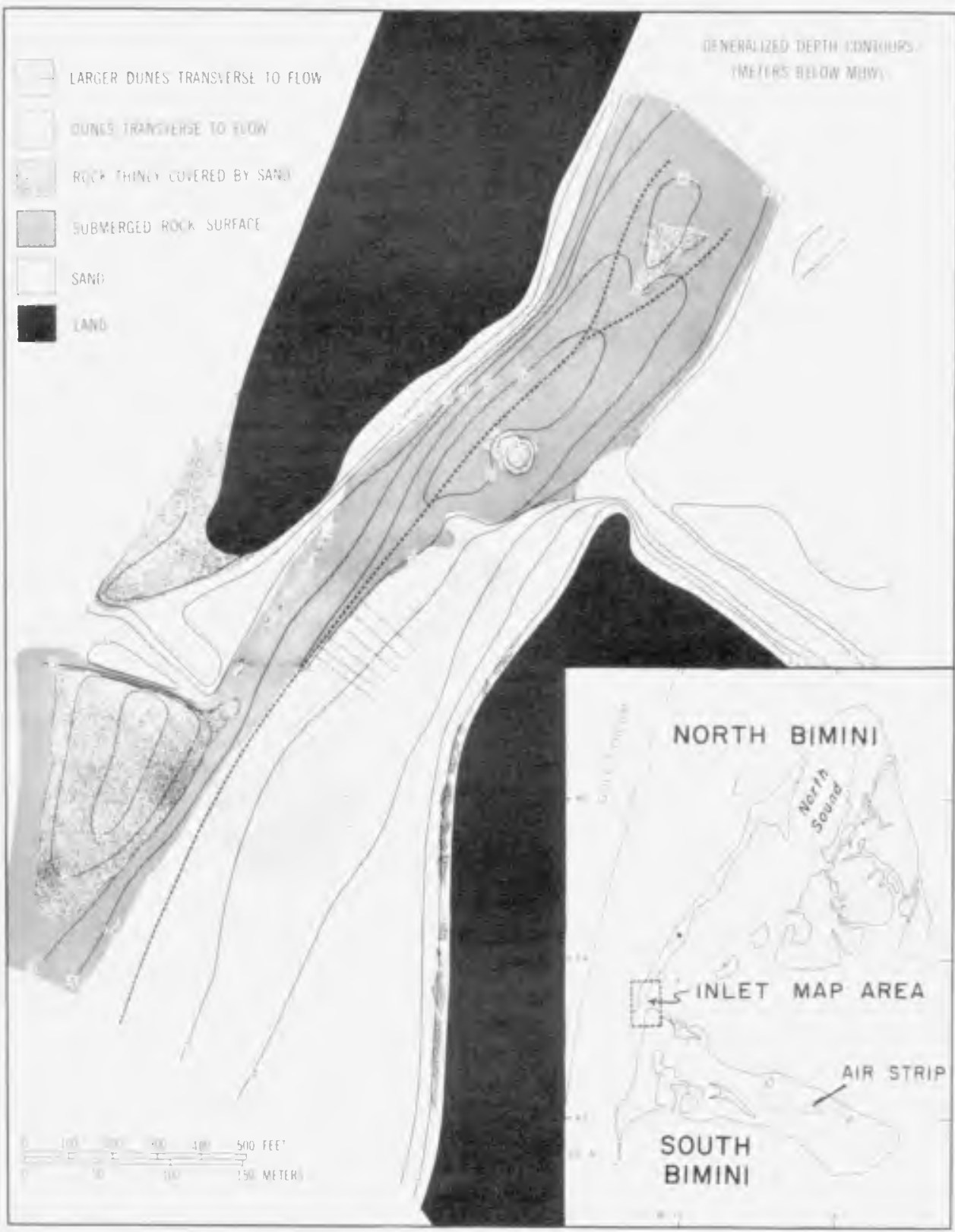

Figure 1.- Location, generalized bathymetry, and geology of Bimini Inlet channel. 
Turekıan (1957) felt that the lagoon was "host to three distınct water masses i) an Indlgenous mass that moves in and out of the North Sound with the tides, 2) a mass entering from the Florida stralts through Entrance Pount, and 3) a mass enterang from the Bank" to the east

The tıde range at Bımını varıes between about 25 to $30 \mathrm{ft}$ and sea level tends to rise or fall together at both Bımını and Mlaml (Wunsch, et al , 1969) Tides are of the semldiurnal type with a slight diurnal. inequality Propagation of the tide wave through the open lagoon is such that the ebb flow (to the southwest) through the inlet is about 30 percent longer than the flood

Current speeds in the northern, constricted part of the inlet channel (FIg 1) are high enough to sweep sediment from the beachrock floor Some of the larger dunes in the central portion are composed of fragmented shell gravel ThIs glves way to sand with median graln diameters of 06 to $08 \mathrm{~mm}$ in the southern portion of the channel Most of the grain surfaces in sand samples of shell hash taken from the central and southern portions of the inlet exhıbıt a glazed appearance when viewed under the bınocular mecroscope Sand-graln surfaces become more chalky, however, as one moves lagoonward (Bathurst, 1967) The specıfıc gravity of sand graıns from elght samples in the area of "dunes transverse to flow" (FIg l) was 284

During the period of study, November 5-13, 1967, water temperature in the inlet channel varied between $20^{\circ}$ and $27^{\circ} \mathrm{C}$, salinity between 34 and $38 \%$, and density between 10201 and $10267 \mathrm{~g} / \mathrm{cm}^{3}$ In May, 1955, Turekıan (1957) found that salinity in the inlet varied between 360 and $370 \%$ and temperature ranged between 263 and $286^{\circ} \mathrm{C}$ over one tidal cycle

\section{DETERMTNATION OF INLET GEOMETRY}

Existing nautical charts of the Bimini Islands (British Admiralty Surveys of the $1840^{\circ} \mathrm{s}$ ) inadequately define the inlet geometry Considering the general clarity of water at the inlet, it was decided to attempt bottom contouring by standard photogrammetric techniques

To provide horlzontal control for aerotriangulation, a base line 2319 ft in length was established by electrotape Each end of the base line was pre-marked with a 4-x-4-ft, red plywood panel, the north end of the base being on North Blminl and the south end on South Bimln

Five vertical control pounts on land were also established and pre-marked in the same manner The levels were run with a Zelss Opton level and were based on a tidal bench mark on North Biminl

The photography as planned placed some photo centers over water wath land areas on only one side To facllitate the clearing of models during both aerotriangulation and compllation, seven floating targets (4-x-4-ft plywood) were anchored offshore to provide photographic images 


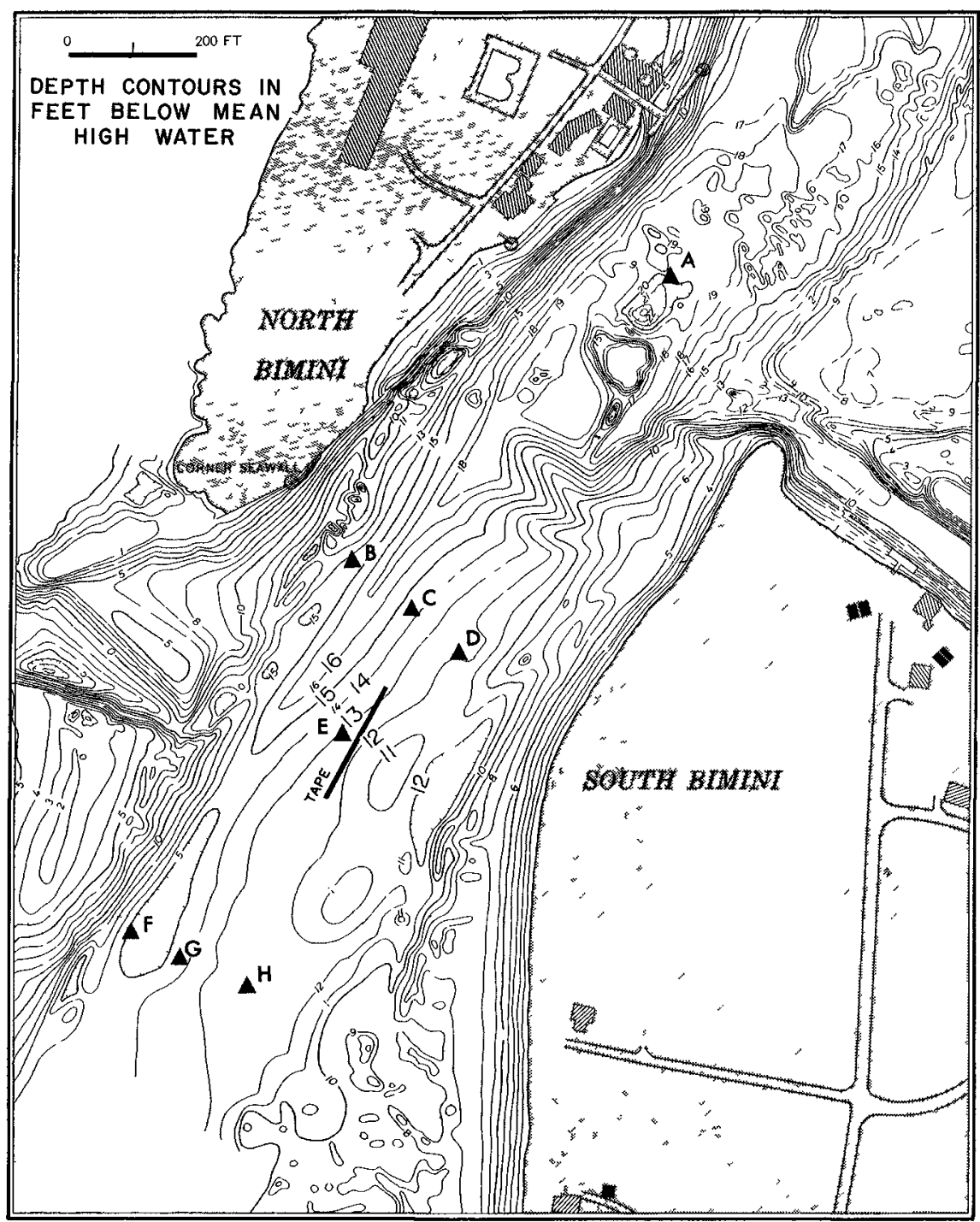

Figure 2 - Detalled bathymetry of anlet, locations of bottom-mounted sensor packages, and position of reference tape 
A WIId RC-8 camera with a focal length of $15229 \mathrm{~mm}$, mounted in an Aerocommander alreraft, was used to obtain the photography on September 8 , 1967 Fl.m was Anscochrome D-200 with an ASA rating of 165 The flylng helght was $2000 \mathrm{ft}$ above mean sea level, resulting in a photograph scale of approximately 14,000

Aerotriangulation was by stereoplangraphic methods using drilled glass plates The contouring of the bottom (Fig 2) was accomplished on a Wild B-8 Plotter at 12,400 scale with a contour interval of one ft The average correction for the refraction index of water for the models contoured was 14

Hydrographic check Innes run 45 days later indlcated that the depth contours ( $F_{2 g}$ 2) were whthin \pm 025 to 0 5-ft for the shallow-water areas of the inlet The "larger dunes transverse to flow" (FIg l) were adequately brought out in the bathymetric contours and the hydrographic check lines showed them to be essentialiy stationary over the 45 days that had elapsed since they were photographed

\section{DOCUMENTATION OF FLUID PROPERTIES, WATER IEVEL, AND FLOW}

Two trupod-mounted, "Geodyne" sensor packages were installed at each of the elght stations $(\mathrm{A}-\mathrm{H})$ shown on Figure 2 Each sensor package contained a platınum thermometer for measuring temperature, a torroldal cell for conductivity, a Savonzus rotor for current speed, and a vane for current direction A given pair of instrument packages were mounted in the tripod so that the Savonus rotor of one was one ft above the bottom whlle that of Its companion was elght ft above the bottom The mounting configuration was such that the flow pattern around a given rotor or vane was unaffected by the tripod legs or by the adjacent sensor package

Each tripod was placed on a level part of the bottom and the sensor packages were hardlıned to one of four shore-based stations Each shore station contained a magnetıc tape recorder and a radio transmitter $A$ given sensor was interrogated every six minutes, each interrogation involving five separate readings of current direction and speed and one each of temperature, conductivity, and reference

Data from the four shore-based transmitters were sent by an RF IInk to a master station at the Lerner Marine Laboratory on North Bumini At the master station, all data from the 16 sensor packages were recorded sequentially on computer-compatıble magnetıc tape The entire system of sensors was continuously operated from 5 November through 13 November, 1967

A bubbler-type tide gage was installed on North Biminl, the orifice was attached to the tripod at Station B 


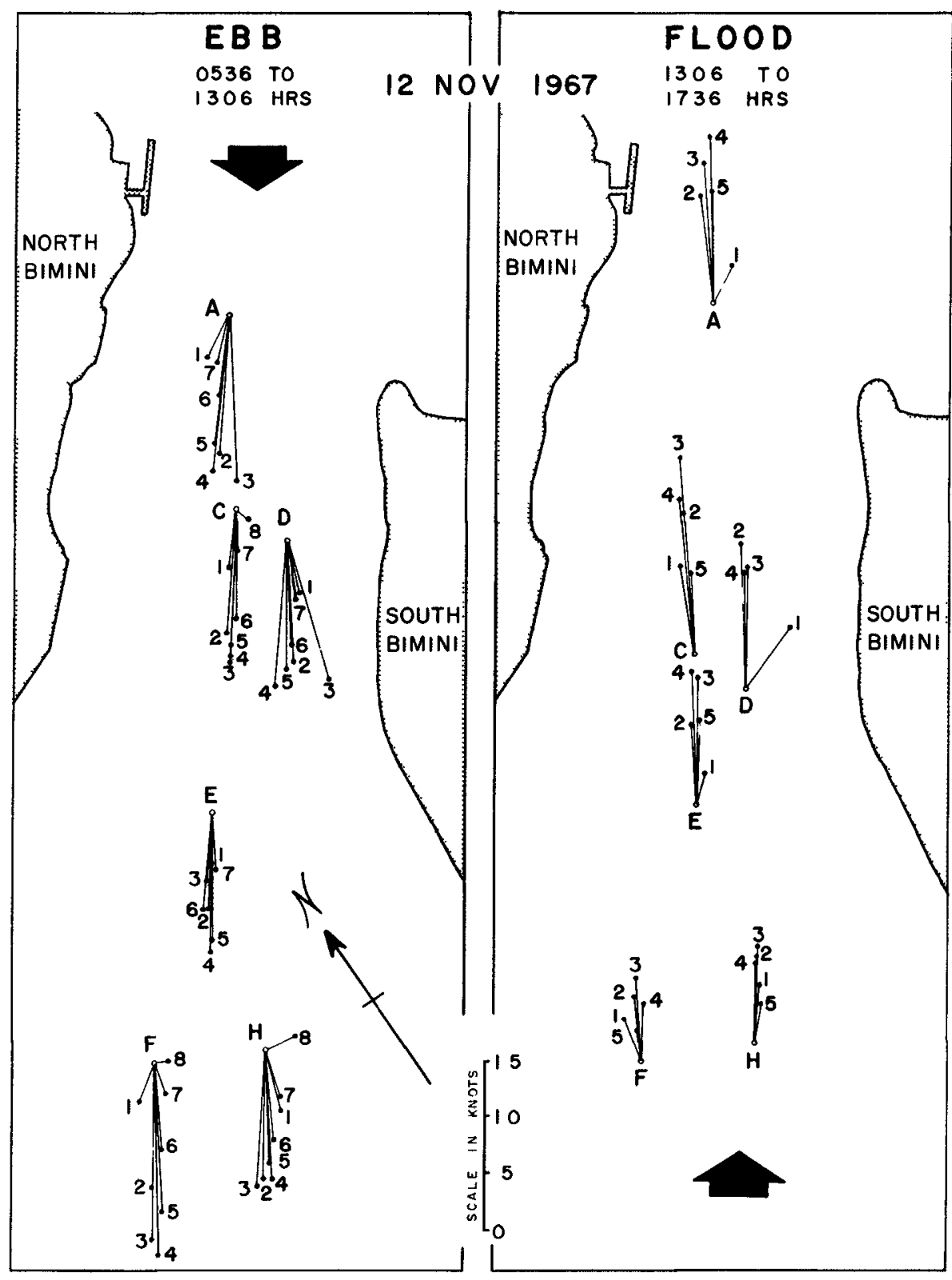

Flgure 3 - Tidal-current vectors for a neap-tıdal cycle ( In hours after high-slack or low-slack water) 
Data on maximum flow elght ft above the bottom are presented in Table 1 The absolute peak speed measured does not appear in Table 1 because it occurred prior to having all elght stations operational This peak speed was 41 knots and was measured eight ft above the bottom at Station A The time of measurement was during a maximum ebb flow that colncided with spring tides and a strong wind from the northeast that had been blowning for several hours

TABIE 1 - NEAR-SURFACE VEIOCTTIES AT SELECTED STATIONS (5 Nov 67, through 13 Nov 67) ( $F=$ flood current, toward $N E$ into lagoon, $\mathrm{E}=\mathrm{ebb}$ current)

\begin{tabular}{|c|c|c|c|c|c|}
\hline $\begin{array}{l}\text { SENSOR } \\
\text { STATION } \\
\left(\begin{array}{ll}\text { fig } & 2\end{array}\right)\end{array}$ & $\begin{array}{c}\text { MAXIMUM } \\
\text { VEIOCITY } \\
\text { (kts, flood or ebb) } \\
\text { (direction, true) }\end{array}$ & $\begin{array}{l}\text { TIME } \\
\text { (date) } \\
\text { (hours, } \\
\text { EST) }\end{array}$ & $\begin{array}{l}\text { AVERAGE } \\
\text { VELOCIT } \\
\text { flood } \\
\end{array}$ & $\begin{array}{l}\text { AXIMUM } \\
\text { (kts) } \\
\text { ebb }\end{array}$ & $\begin{array}{l}\text { AVERAGE DEPTH BEIOW } \\
\text { SUREACE TO ROTOR ( } f t \text { ) } \\
\text { (AIl rotors elght } \\
\text { ft above bottom) }\end{array}$ \\
\hline A & $\begin{array}{c}23 \mathrm{~F} \\
31^{\circ}\end{array}$ & $\begin{array}{lll}5 & X I & 67 \\
2142 & \text { hrs }\end{array}$ & 17 & 17 & 105 \\
\hline$c$ & $\begin{array}{l}28 \mathrm{E} \\
190^{\circ}\end{array}$ & $\begin{array}{l}17 \text { XI } 67 \\
0824 \text { hrs }\end{array}$ & 17 & 19 & 40 \\
\hline$D$ & $2 \underset{04^{\circ}}{1} F$ & $\begin{array}{l}6 \text { XI } 67 \\
0936 \text { hrs }\end{array}$ & 13 & 15 & 27 \\
\hline $\mathrm{E}$ & $\begin{array}{l}22 E \\
213^{\circ}\end{array}$ & $\begin{array}{rl}11 \times I & 67 \\
0618 & \text { hrs }\end{array}$ & 13 & 17 & 33 \\
\hline $\mathrm{F}$ & $\begin{array}{l}33 \mathrm{E} \\
195^{\circ}\end{array}$ & $\begin{aligned} 11 \text { XI } & 67 \\
0824 & \text { hrs }\end{aligned}$ & 10 & 20 & 57 \\
\hline $\mathrm{H}$ & $\begin{array}{l}26 \mathrm{E} \\
234^{\circ}\end{array}$ & $\begin{array}{l}6 \text { XI } 67 \\
\text { ol } 42 \mathrm{hrs}\end{array}$ & 16 & 14 & 40 \\
\hline
\end{tabular}

An 1 dea of tidal-current speeds and directions during a neap-tide flood and ebb cycle may be obtalned from the vectors of Figure 3 It is interesting to note that the directional spread is less than $21^{\circ}$ (Station D, ebb) at all stations during relatıvely strong flows

An example of pulsations in the flow, for the upper rotor at Station $\mathrm{E}$, is shown in Figure 4 Pulsations of this type were observed at all sensors and generally were of 12 or 18-minute frequency spectral analysis with a boxcar window falled to reveal any obvious power at these relatively high frequencies Significant power was found at the tidal frequencies (6 7 and 123 hours) and at the sub-tidal frequency of 43 hours Power peaks of possible significance were also noted at all stations at frequencies of 24 and 32 hours 


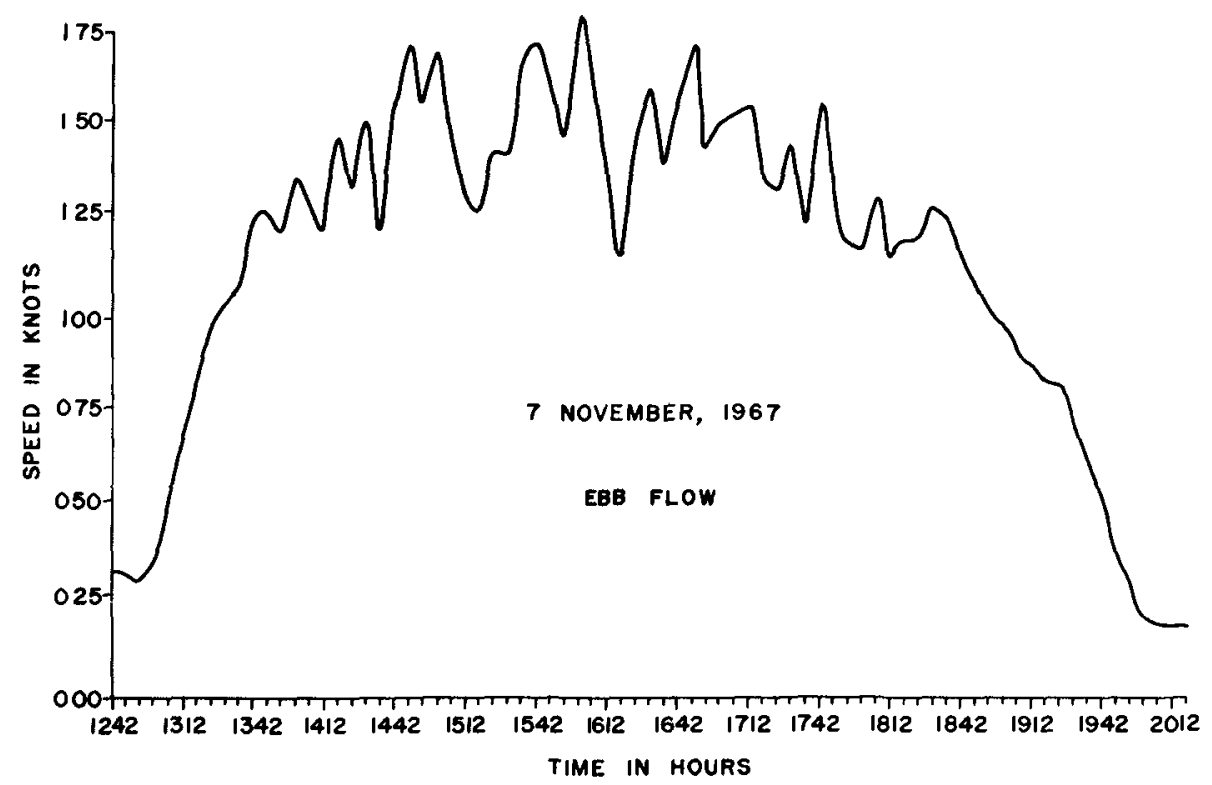

Flgure 4 - Flow pulsations at upper rotor (elght feet off bottom) at Station $E$ (F1g 2), during ebb flow

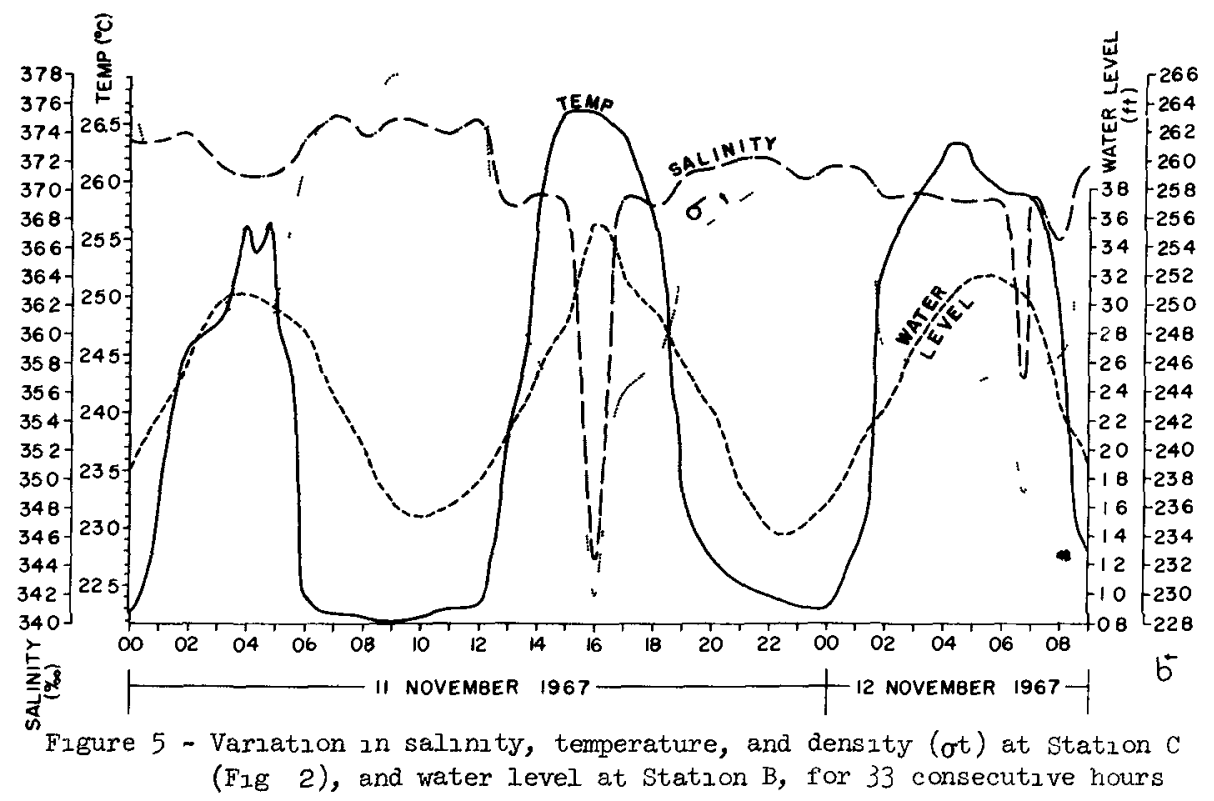


A portion of the curves for variations in temperature, salinity, and sigma-tee at Station $\mathrm{C}$ and water level at Station B are plotted in Figure 5 The inverse relationship between sigma-tee and water level is due to the fact that in November, cooler, more-saline, high-density water flows out of the lagoon on ebb tide This water is completely replaced at high tide by warmer, lower-salınıty, less-dense Gulf Stream watex No density stratification was observed in this shallow channel of well-mixed waters

\section{BEDFORM MORPHOLOGY}

\section{Measurement Procedures}

The goal of the bedform montoring program was to measure changes in geometry and position of the various forms through the reversing fllow of one tidal cycle A falrly complete run was made on 13 November 1967 It started near the beginning of ebb flow and continued through one-half of the flood

Photographic technuques were the prime tools in maknng the bedform measurements Early in the survey a 200-ft, rigld tape measure (graduated in I-ft intervals) was installed about one ft above the Irregular bottom (Fig 2) About $15 \mathrm{ft}$ to the west of the tape, and parallel to It, a wire gulde-line was installed five ft above the bottom The gulde-line served to mantain the diver-photographer at a uniform distance from the tape and allowed hym to control his progress in the rather swift flow A second diver positioned hamself behind the 200 $\rightarrow \mathrm{ft}$ tape The second diver pushed a fork-like device into the sediment so that the elevation of the bed relative to the tape measure could be photographed The fork device was composed of a serıes of $1 / 4-1 n$ rods welded at a 0 5-ft spacing to a rigld cross-member Each rod was graduated in 0 l-ft intervals The rigid cross-member had a bubble level cemented to it so that the upper member was horizontal, which in turn insured that the rods were vertical Two forks were used, each was six ft long and three ft hlgh

A typical run was executed as follows Two divers would descend at the upstream end of the tape one diver would take the two forks to the tape and insert them, end to end, into the bed The photographer-diver then took a stıli plcture from the gulde-line position The other diver would then remove the upstream fork and place it in the downstream position for another photo, and so on A single-photograph sequence of the bedforms generally took thrrty munutes Immediately before or after the still-camera sequence a run was made with a 16-mm movie camera From the developed stıll-camera sequence, the configuration of sand bed relatıve to horizontal was reconstructed 

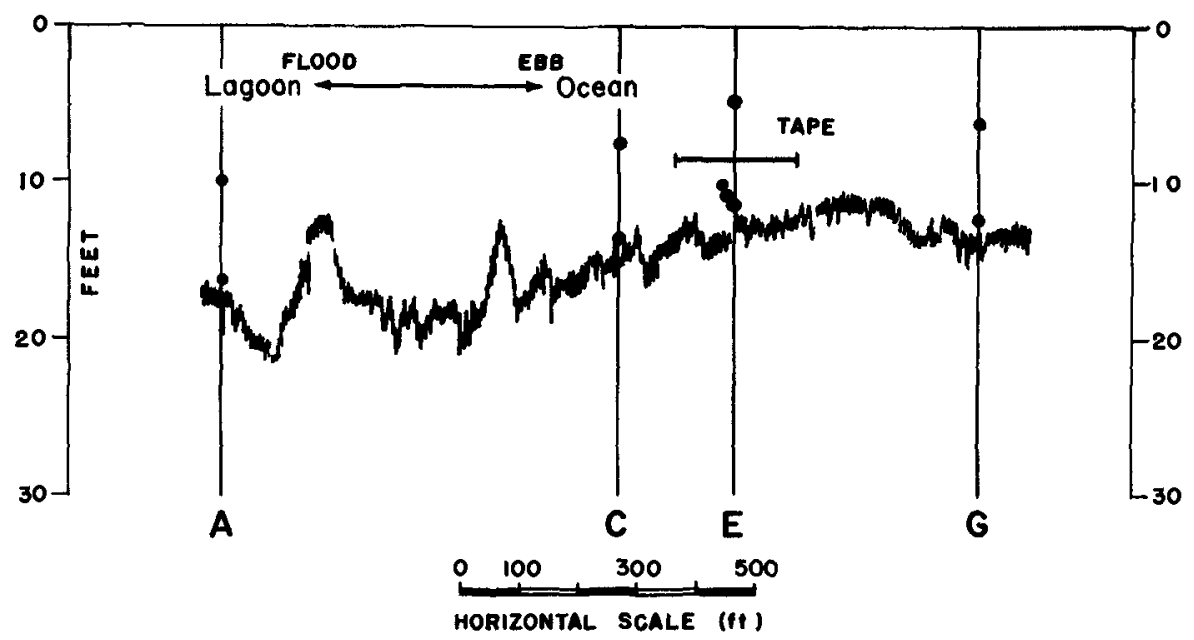

- CURRENT METERS

Figure 6 - Fathometer profile from sensor Stations A to $C$ to $E$ to $G$ and vertical position of current meters

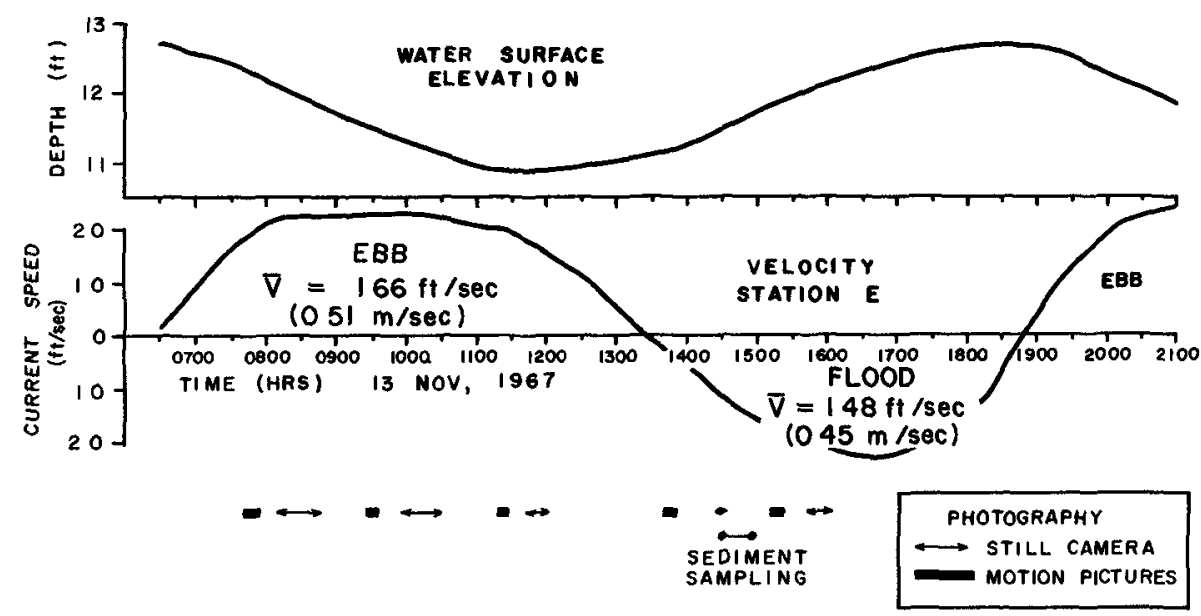

Fugure 7 Flow history and sampling times at Station E, 13 Nov, 1967 


\section{Field Setting}

At any given time during the study three bedform length scales could be observed sand waves dunes, and ripples Inspection of Figure 1 shows that the sand waves exist only on the easterm side of the channel The dunes were long crested, the crest length being 10 to 15 times the wave length A fathometer run from stations $A$ to $C$ to $E$ to $G$ (FIg 2) Is shown in Figure 6 There is a large rock outcrop at the northern end of the throat of the Inlet, about $150 \mathrm{ft}$ south of station A A series of five sand waves had an average wave length of approx.mately 90 feet The fathometer profile shown was obtalned durlng the slack water following a flood flow The fact that the ebb flow asymmetry still remalns suggests that these bedforms are not strongly influenced by the flood flow Superımposed on these larger features were dunes and rupples that were modified by the reversing flow The position of the 200-ft tape is shown also, Its northerm end rests on the crest of the last sand wave Thus, the bedforms montored included those in the lee of the sand wave crest, as well as those exposed to ebb flows of a converging nature Convergence was due to decreasing water depth in the direction of the southern end of the tape

The water surface time history and the velocity history at Station $E$ on 13 November are shown in Figure 7 Also shown are the times when photographlc sequences of the bedforms were obtalned The velocity history lliustrates the strong asymmetry in duration of the ebb relative to flood flow, which was found to be characteristic for this inlet The velocity history is at a mean relative depth $(\mathrm{z} / \overline{\mathrm{d}}$ ) of 066 (where $\mathrm{z}$ is the helght of the rotor above the bottom and $\bar{d}$ is the mean water depth) The mean velocities (Integrating over the flow duration) for the ebb and flood are, respectively, $166 \mathrm{ft} / \mathrm{sec}$ and $148 \mathrm{ft} / \mathrm{sec}$ In summary, we have a condition in which the ebb flow is generally stronger and of appreciably longer duration Net sediment transport may then be expected to be seaward

\section{Evolution of Bedforms}

The sequence of events in bedform change is shown schematically in Figure 8 where, for descriptive purposes, the cycle Is started at the end of flood ( $F 1 g$ 8a) WIth the reversal of fllow (FIg 8b), the bed sediment is transported up the steep gravity face of the dune to form what dimensionally might be considered the new dune crest A trann of ripples also occurs on the dune flank These mpples are all of smaller amplitude than the one derived from the old edge of the dune crest The dominant ripple length is approximately 1 to $15 \mathrm{ft}$

With continued ebb flow the primary crest overtakes some of the other ripples in Its lee There is a consequent increase in amplitude and the growning ripple slowly becomes a dune (FIg 8c) As the new dune crest advances ( $1 n$ the ebb flow direction, Fig 8d), the ripples in its lee become increasıngly less actıve due to shelterıng action other ripples are then observed translating up the upcurrent flank of the dune These are of small amplitude and approximity 2 to 2 5mft in length (Fıg $8 e, f$ ) 
FLOOD
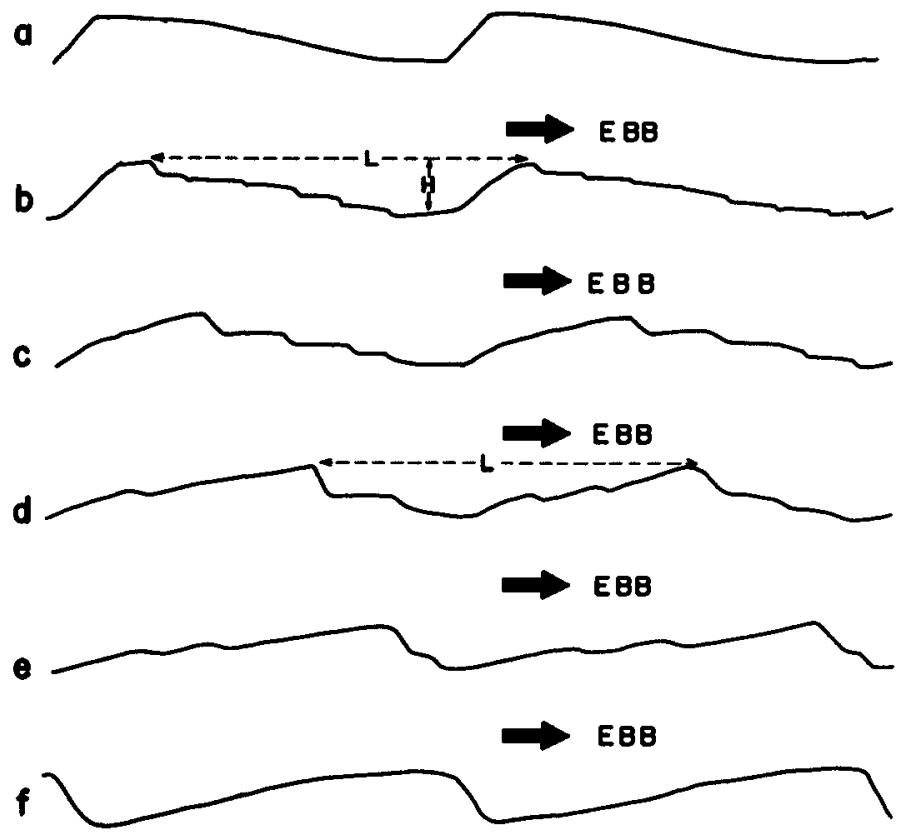

Figure 8 - Schematıc bedform evolution

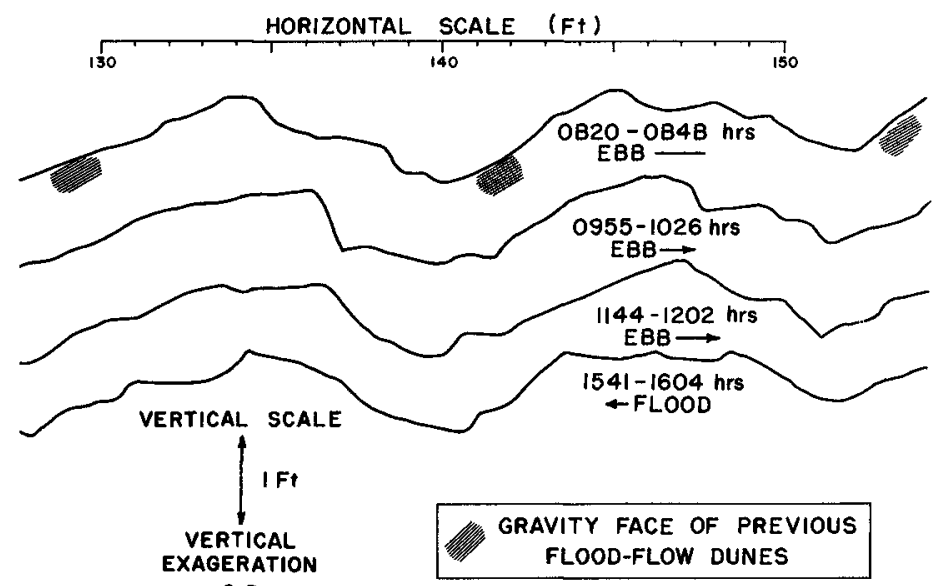

Fıgure 9 - Fxample of observed bedform changes during a tidal cycle 
As the velocity of the ebb flow diminishes the dune crest slows its advance until bed transport stops, at which point the bedforms become dormant until the new Ilood flow is intense enough for grain transport Some of the measured bedform changes are shown in Figure 9 The flow conditions for the various sampling times may be noted in Figure 7

Throughout the study period visual observations indicated most of the sediment transport occured va dune advance wlth no perceptible suspended load Given the aforementioned asymetry in strength and duration of the flow (FIg 7) it migh be expected that the ebb flow dune advance would be greater than the flood flow dune retreat This was observed to be the case over a three day perıod 10 November to 13 November Successive measurements of ebb-flow, dune-crest positions indicated a mean net advance out of the inlet on the order of 1 foot per tidal cycle This value is a very rough estimate as large variability was noted both in time and space

The evolving nature of the dunes presents some problems in determining length characteristics, however, as a flow cycle starts a reversal, a distinctive crest is generated on each dune This crest is the highest point above the downstream trough and It probably exerts a dominant influence on the gross wake characteristics for the dune The dune wave length ( $I$ ) Is defined as the distance between a given domnant crest and the next downstream crest Dune helght $(H)$ Is defined as the vertical distance between the dommant crest elevation and the downstream trough

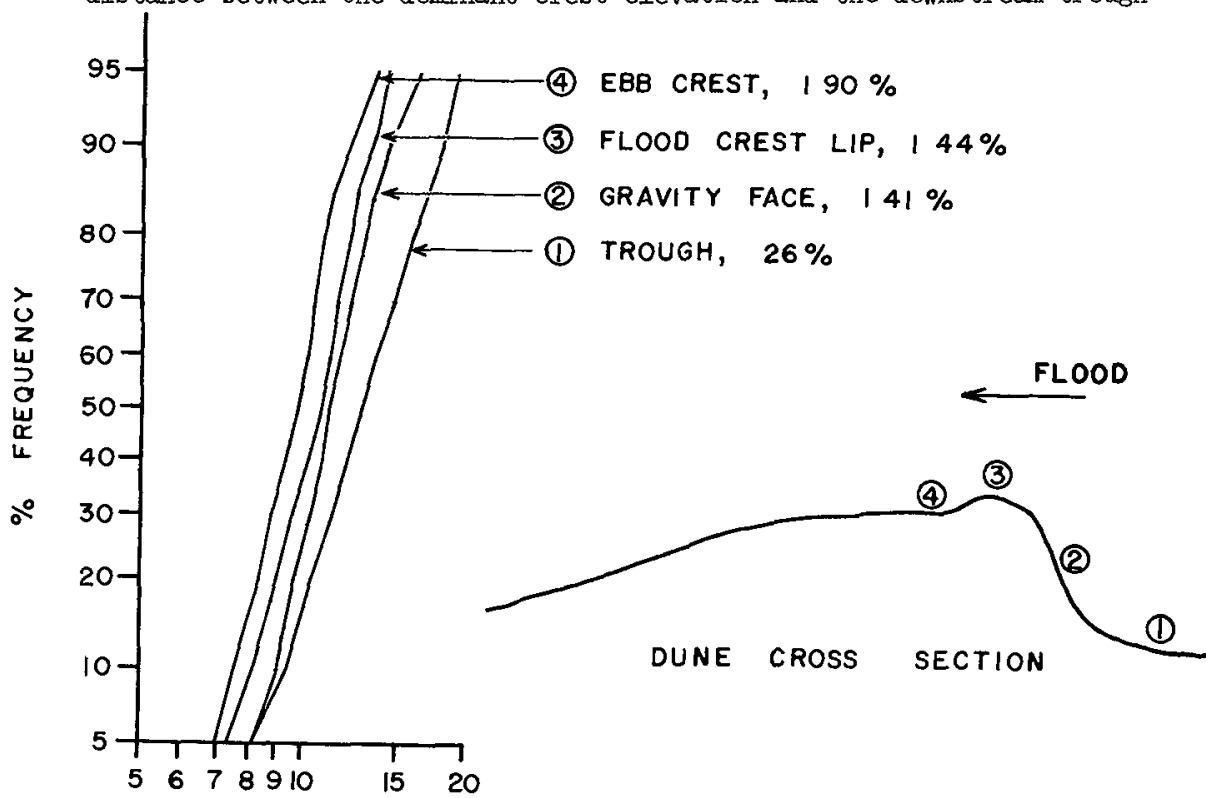

FALL VELOCITY $\mathrm{cm} / \mathrm{sec}$

Figure 10 - Sediment fall velocity distributions welght of material larger than $2 \mathrm{~mm}$ 
Inspection of the bedform profiles over the 200-ft distance indicated that the wave lengths and helghts were signiflcantly different for the northern half (115 ft) of the tape as opposed to the southern half This Is perhaps to be expected, as the first half encompasses those dunes which are formed in the lee of the large sand wave (see Fig 6) The results, cast as averages, are shown in Table 2 Two facts deserve specufic coment First of all, it should be noted that during the ebb flow the dunes in the lee of the large sand wave have longer wave lengths and smaller heights than those beyond the direct influence of the sand wave There Is only scanty evidence for the flood flow, but that avallable (154l-1604 hrs), suggests a uniformity $I n$ dune helght The second point of Interest Is the relative stabllity of wave length and helght (and, therefore, steepness) during the various phases of the reversing flow

TABIE 2 - SIZE PARAMETERS OF DUNES

\begin{tabular}{|c|c|c|c|c|c|}
\hline \multirow[t]{2}{*}{ Parameter } & \multirow[t]{2}{*}{$\begin{array}{l}\text { Position } \\
\text { on Tape (Ft) }\end{array}$} & \multicolumn{3}{|c|}{ Time } & \multirow[b]{2}{*}{$\begin{array}{l}1541- \\
1604 \mathrm{hrc}\end{array}$} \\
\hline & & $\begin{array}{l}0820- \\
0848 \text { hrs }\end{array}$ & $\begin{array}{l}0955- \\
1022 \text { hrs. }\end{array}$ & $\begin{array}{l}1744- \\
1202 \mathrm{hrs}\end{array}$ & \\
\hline \multirow[t]{2}{*}{$\begin{array}{l}\bar{I}(f t) \\
\text { Range of I }\end{array}$} & $0-110$ & 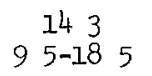 & $9 \begin{array}{l}140 \\
5-200\end{array}$ & $\begin{array}{c}143 \\
100-200\end{array}$ & $\begin{array}{c}156 \\
100-18 c\end{array}$ \\
\hline & $110-200$ & $9^{107} 5-125$ & $\begin{array}{c}109 \\
90-120\end{array}$ & 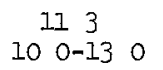 & $\begin{array}{c}105 \\
90-13 c\end{array}$ \\
\hline \multirow[t]{2}{*}{$\begin{array}{l}\bar{H}(f t t) \\
\text { Range of } H\end{array}$} & $0-110$ & $\begin{array}{c}056 \\
0 \quad 27-1 \quad 10\end{array}$ & $\begin{array}{c}063 \\
025-14\end{array}$ & $\begin{array}{l}053 \\
025-120\end{array}$ & $\begin{array}{c}082 \\
025-1=\end{array}$ \\
\hline & $110-200$ & $\begin{array}{c}075 \\
0 \quad 50-100\end{array}$ & $\begin{array}{c}081 \\
0 \quad 60-100\end{array}$ & 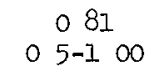 & $\begin{array}{ll} & 080 \\
0 & 50-1 c\end{array}$ \\
\hline \multirow[t]{2}{*}{$\overline{I_{1} / \mathrm{H}}$} & $0-110$ & $\begin{array}{c}30 \\
8-41\end{array}$ & $\begin{array}{l}33 \\
9-68\end{array}$ & $\begin{array}{c}32 \\
11-50\end{array}$ & $\begin{array}{c}25 \\
12-64\end{array}$ \\
\hline & $110-200$ & $\begin{array}{c}16 \\
12-26\end{array}$ & $\begin{array}{c}14 \\
11-20\end{array}$ & $\begin{array}{c}14 \\
10-23\end{array}$ & $\begin{array}{c}15 \\
11-25\end{array}$ \\
\hline
\end{tabular}

\section{Dune Freld Sediments}

Sedument samples were obtanned on 13 November durang flood flow, about one hour after flow reversal Samples were taken of the upper half-inch of the bed material on the dune flanks, crests, and troughs The trough samples are biased, as large fragments of the conch Strombis glgas were not collected Laboratory treatment consisted of a wet separation of the material greater than 2-mm, followed by a settling analysis of the finer fraction 
A.I of the grain-size distributzons from the settling analyses closely approxımated a log-normal distribution with very little variation in the geometric standard deviation, $\sigma 8=W_{84} 1-W_{50}$, which had an average value of about 12 The average median fall velocity of the trough material was about $126 \mathrm{~cm} / \mathrm{sec}$ and at least 25 percent of the material (by welght) Is larger than $2 \mathrm{~mm}$ The seduments composing the dune flank and crest had a somewhat smallex median settling speed $(10-11 \mathrm{~cm} / \mathrm{sec})$ and were generally less than 7 percent greater than $2 \mathrm{~mm}$ in mean size

An example of these results is shown in Figure 10 The sequence shown was obtanned during the flood flow when the flood crest was becoming established Diver observations suggest that the small flood-flow crest is composed of material swept up the ebb-flow gravity face

\section{Flow Profile--Station E}

In an attempt to obtan an estimate of the velocity profile over the dunes an auxiliary current-meter tripod contalning two additional Savonius rotors was placed near Station $\mathrm{E}$ Sampling of the rotors was synchronized with the two tripod-mounted Savonzus-rotors and a sample of 46-seconds: duration was taken every six minutes The relative positions of the four rotors are shown in Figure 6, the lowest rotor was about 1 5-ft above the sand interface, the remaining rotors were 21,32 , and $83 \mathrm{ft}$ above the bottom

During the ebb flow the rotor outputs indicated a larger speed near the bottom than that registered at the uppermost rotor (F1g 6) ThIs pattern persisted throughout the ebb flow until one-half hour before flow reversal at whlch time a normal profile was present Durıng the flood flow the enhancement of flow speed near the bottom was not present, instead, the flow was essentially unform with depth

It seems likely that the flow maximum near the bottom is a jet due to the sand wave field The nature and development of jet flow over sand waves is being studied by $J$ Dungan Smith (Univ of Washington) Smzth (personal communcation) has formulated a model predicting the jet and has documented jet occurrences in tidal flows His early results indicate that the jet amplitude is a maximum when the sand wave height is about $20 \%$ of the water depth and that the jet is fully developed at the fifth wave in the field The bedform conditions of the Biminl Inlet case described here are simlar to those found by smith During flood flow the approach toward unlformaty of velocity wath depth is consistent wath the fact the depth is then divergent downstream

\section{Discussion of Bedform Changes}

Although past studies have delineated the significant varıables that control bedform characteristics in unidirectional. flow, there is no satisfactory formulation to predict the length and amplitude of bedforms found in the fleld It may be anticipated that the problem is even more 
complex in the case of reversing tidal flow There are two man differences between the two cases In the case of tidal flows the time variations in stage (and discharge) for a given flow direction occur in a few hours and bedforms may not come into equilibrium with the maximum flow speeds Carey and Keller (1957), in a study of Mississippl River bedforms noted a bedform size dependence on discharge and postulate a lag between bedform change and change in stage Secondly, with the change in flow direction the flow may encounter (as in this study) an established bedform morphology of reverse symmetry The role of such inltial conditions needs detalled attention

Aside from flow-acceleration effects, it may be anticipated that friction factors during a flow cycle will be somewhat different for reversing flows as opposed to a undirectional flow of equivalent maximum velocity, because the character and position of the separation zone in the lee of the crest changes in time Model studies by Bayazit (1969) for rupples generated by reversing flows indicated fmetion factors less than those found for corresponding unldirectional flows The difference between the two cases was attributed to a possıble lack of bedform equilibrium with the reversing flow In order to avold the effects of acceleration, Bayazit used the maximum velocity in formulating a friction factor

In the absence of detalled studies it has frequently been assumed that bedform development in an inlet may not differ significantly from a corresponding steady flow (Bruun, 1966) If such was the case one might expect to find a progression from mpples to dunes as the velocity increases and the reverse order as the velocity decreases The present study indicates this view is probably oversmplified For this case, the baslc bedform sizes are stable through time with the major changes being simply a reversal of dune geometry It is of interest to compare the dune lengths and helghts observed here whth those observed in unldirectional flow Analysis of field data by Allen (1968) showed that the characteristic lengths of dunes were strongly correlated with flow depth although it was recognzzed that dune size is not a unique function of depth Allen's relationships are, for lengths in meters

$$
\begin{aligned}
& \text { 1) } \mathrm{H}_{\mathrm{D}}=0 \quad 086 \mathrm{~d} \perp 19 \text { and } \\
& \text { 2) } \mathrm{I}_{\mathrm{D}}=116 \mathrm{~d} \perp 55
\end{aligned}
$$

where $H_{D}$ is dune helght, $d$ Is flow depth and $I_{D}$ Is dune wave length Because there was relative stability in the average dune length and helght during the observation period (Table 2), the mean depths over the two tape segments were used to calculate the expected values from equations $I$ and 2 For the lagoon side of the tape the computed wave length is $356 \mathrm{ft}$ whereas the observed mean value is approximately $145 \mathrm{ft}$ The computed dune height is $16 \mathrm{ft}$ and the observed mean is about $06 \mathrm{ft}$ For the oceanside segment of the tape the computed wave length is $282 \mathrm{ft}$ and the observed is about $110 \mathrm{ft}$, for dune helghts we find $132 \mathrm{ft}$ versus an observed value of about $080 \mathrm{ft}$ The expected values from equations $I$ and 2 are thus significantly larger than the observed mean values 
Gencrally it can be sad that the resulting scour is strongly influenced by the pile and the wave characteristics In most of the runs, very little to no bed movement could be observed away from the pile $I$ he pile scrved as a catalyst to start the scoul activity and once started around the pilc it spredd over a large area and extended in some cascs great distances from the pile Figs 9 and 10 show somt typical scour patterns obtaned from the expeiments

\section{CONCLUSIONS AND REMARKS}

1 The critical velocity necessary to cause incipient motion in oscillatory flow appcas to be lowel thin that for steady state flow

2 The idto of the maximum velocity on the pile boundary and the initid free stream velocity, is less than the value of 20 for potential flow theory

3 Incipient motion on the ple boundary appears to be independent of $\frac{\mathrm{H}}{\mathrm{h}}$ and directly dependent on the parameters $\frac{\mathrm{h}}{\mathrm{gT}^{2}}$ and $\frac{\mathrm{d}}{\mathrm{h}}$

$4 \quad \frac{\overrightarrow{\mathrm{Su}}}{\mathrm{H}}$ appears to be dix ectly related to the sediment number $\mathrm{N}_{\mathrm{s}}$ and the pile Reynold s Num

be1 $\mathrm{N}_{\mathrm{RP}}$

5 A maximum of only 6000 waves are required to redch an ultimate scour depth and in most cases 3000 waves are sufficient

6 The rclative ultımate significant scoul depth increases veıy rapidly at tisst, reaching thrce fourths of its ultimate depth in the first 1000 waves, and increases more slowly after that until it reaches its ultimate depth

7 Eddy toices, although initially influcncing the scour patteins, do not appcar to be of signifi cance in the find scoul pattern

8 The scour pattern rosulting is pimarly influenced by the pile and the wive chaldeteistics

9 In all the scour experiments, the pile acted as a catalyst causing scour of the bed particles to be initiated whereas if the pile was not present little to no scour would have iesulted

Io try and predict scour depths for a prototype case or relate these unconclusive results to a pro totype would be presumptuous To piedict happenings or occuriences of a phenomenon in a proto type requires that there be similitude, both geometric and dynamic, between the model and proto type This requiles that similitude exists between the orbital velocities and orbital lengths (1 $c$ wave chal icteistics ac similar), gidm size and grin size distribution in the bed, roughness of the beds, and translation of the oibit duc to drift Without these similitudes ciloneous conclusions could be leached in attempting to piedict piototype conditions The difficultics in acquiring similitude be tween prototype and model were pointed out by Poscy and Sybert 18 in the 11 studics of scour around piles on olfshore platiorms It required scveral years of study and expcimentation beforc actual prototype conditions werc duplicated in the model 


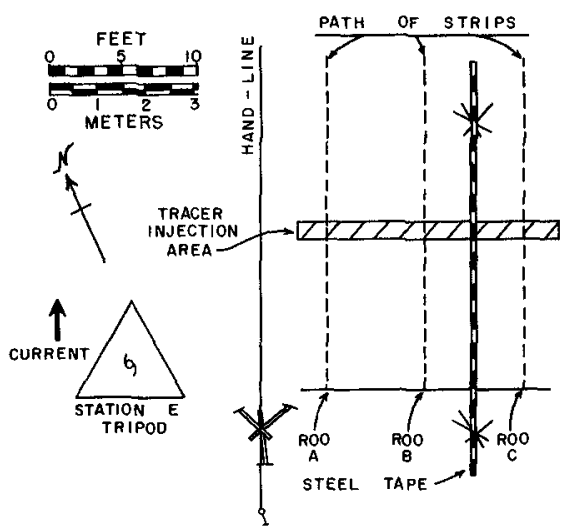

Fızure 11 - Map View of Tracer Experzment Layout

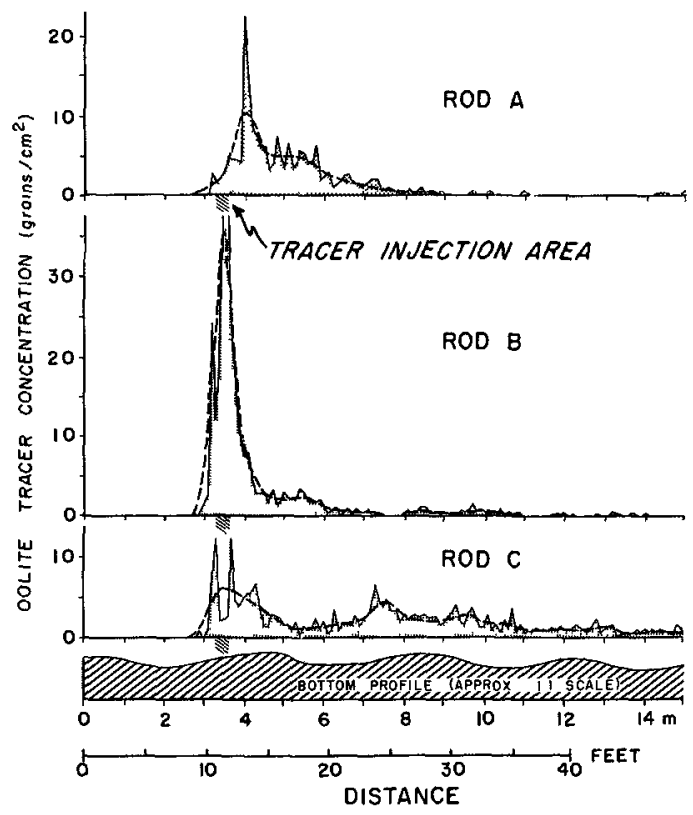

Figure 12 - Plot of Oolıte Tracer Concentration versus Distance for Rods A, B, and $C$ after the First Sampling Run 
Plastic bags contanning the tracers were placed within the anjection area (IIg 11) by a diver who eut them open with a knlfe at the designated time of release Recovery of released tracers was accomplished using $015 \times 18 \mathrm{~m}$ strıps of $\mathrm{K}$ \& E draftıng fIIm (Herculene) Loated with DowCorning 1.03 compound These strups were unrolled on the bottom in a northerly direction parallel to a graduated steel tape Three strips, fixed at one end by steel rods were unrolled simultaneously by divers according to the configuration shown on Figure 11. Four sampling runs were made at 30-manute intervals begnnning at 1307 hours

The recovered sampling strıps were examned in the laboratory under ultraviolet light Tracers were counted withln a $1.0 \mathrm{~cm}^{2}$ grid placed over the strips at $01 \mathrm{~m}$ increments for the full length of the tape Tracer concentrations, expressed as the number of gralns per $\mathrm{cm}^{2}$, were then plotted agannst distance from the holding rods in meters Figure 12 is a plot of the inztial. sampling run for rods $A, B$, and $C$ The dashed curves, intended for smoothing of the data, were obtalned by dividing distance $ı$ to $05 \mathrm{~m}$ class $\mathrm{n}$ tervals and averaging grain concentratıons therein

In examning the data, It was immediately apparent that the quartz grains (0 59-0 $84 \mathrm{~mm}$ ) were present in smaller amounts than the oolite (0 30-0 $59 \mathrm{~mm}$ ) and that their distribution was more limited A few quartz grans traveled as far as $15 \mathrm{~m}$ downstream $\mathrm{n}$ the first 30 munutes after the first release Most of the quartz tracers, however, assumed an almost normal distribution about a point less than $10 \mathrm{~m}$ downstream from the release zone The quartz tracers also appeared to be distrubuted uniformly in a lateral sense as evidenced by simultaneous comparisons between adjacent strips

oolite tracers were recovered in greater numbers and their distribution appears to have been more widespread than that of the quartz materzal Following their release, significant concentrations of oolite $\left(\sim 1\right.$ graln $/ \mathrm{cm}^{2}$ ) were found at maxımum distances from the release zone after 30 minutes, also the greater mass of these tracers, whlle remalning some l-2 $\mathrm{m}$ downstream from the release zone, showed markedly skewed distributions toward the downstream side (F1g 12 , Rods $A$ and $B$ ) with pronounced $b_{2}-$ or trumodallty 1 many cases (Fig 12, Rod C) Moreover, the oolite tracers often showed great lateral varıability, as seen through the simultaneous comparisons of adjacent strips, and temporal. variability, as seen in tume-sequential comparisons along each of the strip paths

A bedform profile, obtanned from photographs at the end of the flood current, is included in Figure 12 to show the relation of tracer concentration to bedforms

In order to quantify the observed lateral and temporal variabılıty in ollte tracer distribution, a two-way analysis of variance (Rods versus Runs) was conducted using the oolite data of the four runs for rods $A, B$, and $\mathrm{C}$ The variable used in the analysis was tape distance in meters with 
TABIE 3 - IWO-WAY AIALIYSIS OF VARIAITCE OF TRACER RECOVERY DATA (Varıable Is Tape Djstance in Meters Tracer oolite)

\begin{tabular}{|c|c|c|c|c|c|}
\hline ROD & SAMPLE & $\begin{array}{c}\text { RUN } \\
1\end{array}$ & $\begin{array}{l}\text { RUI } \\
2\end{array}$ & $\begin{array}{c}\text { RUN } \\
3 \\
\end{array}$ & $\begin{array}{c}\text { RUN } \\
4 \\
\end{array}$ \\
\hline A & $\begin{array}{l}\text { Mean } \\
\text { Var } \\
\text { Size }\end{array}$ & $\begin{array}{l}492 \\
131 \\
188\end{array}$ & $\begin{array}{ll}3 & 63 \\
0 & 17 \\
180\end{array}$ & $\begin{array}{c}408 \\
021 \\
48\end{array}$ & $\begin{array}{c}459 \\
066 \\
47\end{array}$ \\
\hline B & $\begin{array}{l}\text { Mean } \\
\text { Var } \\
\text { Slze }\end{array}$ & $\begin{array}{ll}3 & 83 \\
0 & 52 \\
302\end{array}$ & $\begin{array}{c}390 \\
018 \\
81\end{array}$ & $\begin{array}{l}459 \\
112 \\
461\end{array}$ & $\begin{array}{ll}4 & 43 \\
0 & 55 \\
155\end{array}$ \\
\hline C & $\begin{array}{l}\text { Nean } \\
\text { Var } \\
\text { Size }\end{array}$ & $\begin{array}{l}606 \\
464 \\
200\end{array}$ & $\begin{array}{l}358 \\
0223 \\
55\end{array}$ & $\begin{array}{c}429 \\
021 \\
021\end{array}$ & $\begin{array}{c}400 \\
048 \\
97\end{array}$ \\
\hline
\end{tabular}

\begin{tabular}{|c|c|c|c|c|c|}
\hline $\begin{array}{l}\text { VARTATION } \\
\text { SOURCE }\end{array}$ & $\begin{array}{c}\text { SUMS } \\
\text { Of } \\
\text { SQUARES }\end{array}$ & $\begin{array}{l}\text { DEGREES } \\
\text { Of } \\
\text { FREEDOM }\end{array}$ & $\begin{array}{c}\text { MEAN } \\
\text { SQUARE }\end{array}$ & $\begin{array}{c}F \\
\text { VALUE }\end{array}$ & $\begin{array}{c}\text { CONPIDENCE } \\
\text { IEVET } \\
\text { (PERCENTAGE) }\end{array}$ \\
\hline TOTAL & 297763 & 1834 & & & \\
\hline INTERACTION & 45905 & 6 & 7651 & 6741 & $>99$ \\
\hline ERROR & 207400 & 1828 & 113 & & \\
\hline ROD & 17852 & 2 & 8926 & & \\
\hline RUN & 26529 & 3 & 8843 & & \\
\hline
\end{tabular}

the number of gralns recovered at a particular distance serving as a frequency Index for that distance Each sample of tape distances was therefore an indicator of the distribution of the tracer population for which a mean and a varıance could be estimated

The object of the analysis was to determine whether or not tape distances could be pooled for all three rods and a separation of tape distance means effected between runs After the analysis was run, significant interaction indicated that pooling could not be done and therefore separation of the means was not possible Table 3 gives the results of this analysis 
A sımlar analysıs was attempted for the quartz tracers However, by using a one-way analysıs of varıance inltually, it was learned that none of the means for runs could be separated due to their close simlarity in value and the slgniflcant varlance within each run This result only confirmed the visual impression that the quartz tracers evidenced very lıttle bulk movement

\section{DISCUSSION}

The results obtanned suggest that the oollte tracer exhybited a greater tendency toward transport than did the quartz tracer Probably the oolite tracer was "undersized" for the existing flow regime in the inlet whlle the quartz tracer was close to the prevaling grain sizes on dune crests Compared wath the greater ebb current speed obtalned at Station E (Av 17 knots, $\max 22$ knots) It is not surprising that the flood current seemed to transport only a few quart $z$ grains and that the distrıbutions of these were less skewed Caution must be used in this interpretation, however, because the effect of burlal of tracer gralns is unknown due to the sampling method employed It has been Instructive to the authors that an inlet such as the one at Bimini represents an extremely complex environment and even detalled measurements are inadequate for a clear picture of the way in which sand is transported For example, lateral variablilty of apparent grain motion was much more evident than anticipated, bottom transport is truly a three-dımensional problem

Although the results of the experiment are not conclusive, it seems evident that dunes play a major role in the distribution of tracer sands, and the modes of the concentration curves indicate points of grain accumulation which move slowly downcurrent with time In some cases, grains apparently travel very quickly over a succession of dunes, but a majority of samples indicate that most of them are fixed by the dune topography and therefore travel at much slower rates This slow transport is in keeping with the fact that the dunes themselves migrate very little durıng any given tidal cycle

The Blminl Inlet sedıments appear to possess an organic coating (Bathurst, 1966) which did not allow most of them to adhere to the greased sampling strıps All tracer grains were thoroughly dried and rewetted with detergent before release, they adhered very well to the strips Although mucold coatings or gelatinous mats are not cormon to the active sands typlcal of the Bıminl Inlet (Bathurst, 1966, p 90), there was clearly a difference in the surfaces of the in-situ and tracer grains This then leaves the question of whether or not the in-situ grains experience a binding effect that is not otherwise apparent 


\section{ACKNOWLEDGMENTS}

All of the fleld work for this study was supported by the Atlantic Oceanographlc and Meteorologlcal Laboratories, of the Environmental Science Services Administration (ESSA), Miami, Florida Logistical support was obtalned from the Lerner Marıne Laboratory (American Museum of Natural History) on North BIm工nI Aerial photography and contour mapplng was accomplished by the Photogrametry Division, Coast and Geodetic Survey, ESSA

This study could not have been accomplished without the concerted efforts of many indlviduals We wish to express our great appreciation to Messrs $F$ Beugnet, $S$ Cofer, J Falkenhoff, B G Grant, C Kıersh, $M \quad P$ Lynch, $E$ W Rayfield, $G$ Reynolds, and $D G$ Tyler for their efforts in the field $R$ W Mathewson and his staff at the Lernex Laboratory were also most helpful in the field effort

\section{REFERENCES}

Allen, $J \quad R$ I 1968 The nature and origin of bedform hierarchies Sedımentology, $10161-182$

Bathurst, $R$ G C 1967 Dolite fllms on low energy carbonate sand graıns, Bımın lagoon, Bahamas Marıne Geology, 5 89-109

Bayazıt, M 1969 Resistance to reversing flows over movable beds Proc ASCE, Jour Hydraulics Div, 95(July 1109-1127)

Bruun, P 1966 Tidal Inlets and Inttoral Drzft, $v 2$, Skıpnes offsettrykkerı, Trondhe.m, Norway, $p$ 1-193

Carey, W C and H D Keller 1957 Systematic changes in the beds of alluvidal rivers Proc ASCE, Jour Hydraulic DIv, 85(August 1-24)

Turekıan, K K 1957 Salınıty varıatıons in sea water in the vicınıty of BımıI, Bahamas, B W I, Amer Museum Novitates, No 1822 , $12 \mathrm{pp}$

Wunsch, C, D V Hansen, and B D Zetler 1969 Fluctuations of the Florida current inferred from sea level records Deep Sea Research (SuppI) $16447-470$

Yasso, W E 1962 Fluorescent coatıngs on coarse sediments, an integrated system Office Naval Research, Geog Branch, T'ech Rep I, $48 \mathrm{pp}$ 